\title{
Discuss the Accounting Information Risks and Preventive Measures Based on Big Data
}

\author{
Manping Weng ${ }^{1}$ Dongdong Weng, ${ }^{2, *}$ \\ ${ }^{1}$ Liming Vocational University, Fujian, Quanzhou, China \\ ${ }^{2}$ Xiamen Institute of Technology, Fujian, Xiamen, China \\ *Corresponding author. Email: weng28911985@163.com

\begin{abstract}
Combining the correlated theory in risk factors of accounting informatization at home and abroad with the practice of the promotion of accounting informatization in Chin enterprises, this paper puts forward the preventive measures to avoid risks that might occur during information construction decision, data information processing, personnel changes and asset protection. These measures make the accounting information transfer more stable and safer, so that accounting information towards a healthy and bright direction.
\end{abstract}

Keywords: Big data, Accounting informatization, Cloud computing, Preventive measures.

\section{RISKS OF ACCOUNTING INFORMATIZATION IN THE ERA OF BIG DATA}

\subsection{Information System Risk}

For now, domestic cloud computing technology is still immature and still needs further improvement. When an enterprise builds an information sharing platform based on cloud computing technology, it needs to bring in professionals for construction and provide operation and maintenance services. Enterprises, and in economic data forecasting and cost estimation, when the business process is shared, plus, the feedback of platform construction after the completion of the business is slow. The feedback of platform construction after the completion of the business is relatively slow. As the basic equipment of accounting informatization, only a more complete resource sharing platform can effectively promote the development of accounting informatization [1-3]. However, if the construction period of the information sharing platform is long, it will directly affect the efficiency of the platform's resource use, and thus affect the platform's resource sharing capabilities.

\subsection{Data Information Processing Risk}

\subsubsection{Lack of Data Analysis Technology}

Traditional structured information can be analyzed more deeply based on data mining algorithms, but the processing and analysis of semi-structured or unstructured data is more complex, and it is difficult to perform in-depth analysis of it using traditional data algorithms, which will affect information analysis The timeliness and efficiency of analysis affect the effect of information application. Therefore, it is necessary to optimize and upgrade the existing information analysis technology of the enterprise and introduce newer data mining technology. Only in this way can the timeliness and effectiveness of information analysis be ensured With the advent of the era of big data, although accounting information systems have freed accountants from complex manual operations, the pressure on financial personnel is still considerable [4-5]. Moreover, while the amount of data is gradually increasing, some information data may not be converted into effective data in the short term. Under the big data model, higher requirements are placed on data accuracy. The accuracy mentioned here refers to the accuracy of the data itself. On the other hand, it refers to the accuracy of data processing results, which will directly affect the results of data processing and analysis. 


\subsubsection{Weak Accounting Treatment of Enterprises}

In recent years, the development of network technology has been very rapid. From the elderly to children, netizens have gradually spread all over the world, and the Internet has become an indispensable part of people's daily work. Internet-related technologies are penetrating into more and more industry fields. In this context, financial accounting should continue to innovate in line with the development needs of the times, and the thinking consciousness and professional capabilities of its practitioners should be changed. As long as financial accounting has the corresponding level of science and technology, and through science and technology to better serve the work. However, as far as the actual development is concerned, there are still some accounting staff with low technological level and insufficient operational level, which to a large extent leads to their low efficiency in the actual work process. Therefore, the relevant management personnel in the enterprise must continuously cultivate the technical level of the accounting personnel, and in the actual work process [6-7], make them aware of all the serious consequences that the problem may bring, and ensure that their practical operational capabilities can develop at the same time. The trends coincide. Only in this way can accountants in enterprises better serve the financial accounting industry.

\subsection{Risks of Financial Practitioners}

\subsubsection{Risk of Financial Staff Thinking Change}

In the current development background of the rapid spread of big data, traditional accounting can only handle relatively simple financial statement analysis, and the content of these financial information is relatively simple, and there are not many future financial plans. It is necessary to change accounting thinking, break away from pure financial work, and gradually develop in the direction of management accounting. Accounting work has high requirements for the timely, effective, accurate and complete information. If the accounting information does not reflect the development of the enterprise in a timely and accurate manner, it will directly affect the quality of enterprise decision-making, which is not conducive to the sustainable and stable development of the enterprise. In this context, corporate accounting practitioners are required to be familiar with the characteristics of big data technology and have big data thinking, to form a basic understanding of the basic processes of the company's production and operation, and to organically integrate big data technology with the company's business to promote the realization of the company Better development

\subsubsection{Shortage of Accounting Information Talents}

Accounting information involves knowledge fields such as accounting, computer technology, and management science. The successful implementation of corporate accounting information depends on the combination of computer and financial talents. Talent is an important part of accounting information construction. The use of information technology in the clothing industry is not professional enough, and there are specialized information management positions and personnel. There is a lack of comprehensive talents such as computers and accounting, and some accountants lack a certain degree of professionalism and scientificity in using computer software. Because companies do not use computer technology in their business processes. Moreover, in terms of computers, we did not spend too much money to match some professional talents, which resulted in a relatively low overall quality of employees. In addition, in the process of enterprise management, there are still some people who do not understand the construction of accounting information, or even have no in-depth understanding of the construction of accounting information [8-9]. They think that only using computers to summarize some data is unreasonable. The new operating system will also invalidate the information system and platform, causing information and data errors. Accounting informatization is relatively unfamiliar to most accounting personnel. Many accounting personnel have low comprehensive qualities and cannot grasp excellent management experience and methods in time. In the use of the software, there is no clear understanding of the financial software, which is prone to operating errors. Because of some mistakes in thinking, errors in the use of software are caused.

\subsection{Network Virus Intrusion Risk}

\subsubsection{Risk of Foreign Virus Invasion}

With the continuous expansion of the application scope of big data technology in the accounting field, how to improve the security of accounting information in the transmission and application process has become the focus of corporate development. During the development of an enterprise, it is necessary to continuously and dynamically monitor user data, financial data, and operating data of the accounting information system, and take necessary protective measures to reduce malicious tampering from the outside. Generally speaking, the relatively simple authentication procedure of domestic enterprise financial system is the weak link of virus attacks such as Trojan horses. Because the anti-virus software in the enterprise cannot effectively prevent the spread of the virus, it 
cannot systematically kill the virus and prevent its spread. At present, most companies use Windows-based network operating systems, and these operating systems have a large number of unpredictable vulnerabilities, even causing intruders to obtain administrator rights, which in turn makes these intruders continue to refuse Services and other attacks. The information transmitted on the network hides many potential security problems. For example, leaking corporate secrets leads to confusion in corporate data. In addition, these illegal users will also disrupt the normal order of society by sending false information and other methods, causing immeasurable losses to enterprises. Internet technology is often subject to various attacks from hackers in practical applications. Therefore, enterprises cannot transmit relevant information through the Internet under the condition that they cannot ensure the security of their own accounting information. Although this approach improves data security, it is also not conducive to the exchange of information between enterprises. It can be seen that accounting information security issues will directly affect the development of the entire enterprise.

\subsubsection{Low Self-safety Factor}

At this stage, a considerable number of companies are not paying enough attention to accounting network information security in their development, which makes corporate information leakage incidents happen from time to time. How to provide a safe and stable environment for enterprise financial information management is one of the important problems to be solved in the current enterprise information construction. Standardizing and improving corporate management systems will help create a safer and more reliable accounting operating environment for companies. A good internal control system helps to improve the level of enterprise information management. The rapid iteration of information technology has made it possible to tamper with accounting records and related data, and the difficulty of prevention has increased significantly, which has further increased the risks faced by enterprise accounting informatization. At the same time, many companies are not very aware of financial risk prevention, especially not paying enough attention to the security and accuracy of accounting information. The development of the computer industry has brought convenience to people's lives and has also led to the rapid development of the computer virus industry. If computer network security protection measures are not in place, the possibility of financial information being attacked, stolen and tampered will greatly increase. Network security incidents will bring greater losses to the development of enterprises. Therefore, enterprises should attach great importance to the issue of accounting information security in their development, and formulate complete systems and measures to ensure it. 2 "Internet + " financial management personnel training mechanism.

\section{MEASURES TO PREVENT ACCOUNTING INFORMATIZATION RISKS}

\subsection{Improve the Independence of Information Platform}

In the era of big data, the scale of accounting information and data publicly released by enterprises to the society continues to expand, and relevant data analysis requirements continue to increase. The quality of accounting information is directly related to the use of accounting information. Enterprises should establish a dedicated accounting information processing center. Mainly responsible for the compilation of financial data, and do a good job in financial data information disclosure and supervision to ensure the security of corporate accounting information. Through effective internal analysis of financial data, the quality of accounting information has been improved. At the same time, the collection and sorting of accounting information in related industries can provide data support for corporate decision-making. In the era of big data, there are more accounting information collection channels, and the scale of data is increasing rapidly. It is necessary to set up certain positions to process data in order to improve the efficiency of accounting information use. The core of the development of accounting informationization lies in the collection of a large amount of accounting information. The maturity of accounting information collection technology and methods will directly affect the quality and efficiency of accounting information collection.

The level of accounting information platform construction directly affects the quality of accounting operations. Government departments should attach great importance to the importance of corporate accounting for the development of enterprises. In order to improve the quality of corporate accounting information, the government should lead the formation of special funds to accelerate the construction of cloud computing special projects, and integrate corporate financial accounting information through this project. Improve the efficiency of corporate accounting information utilization. At the same time, it is necessary to break the constraints of the traditional accounting system on the development of enterprises from the institutional level, build an accounting system based on accounting informatization, and provide high-quality corporate decision-making on the basis of strengthening the integration of corporate accounting and other business information support. 


\subsection{Strengthen the Data Security of the Information Platform}

When enterprises are engaged in informatization construction, they need to strengthen the security of the information platform system, and provide more targeted maintenance strategies through the analysis of the security risks related to enterprise informatization construction. Information platform management specifically includes the following contents: First, it is important to manage the security of user identity authentication. According to actual needs, multiple certification bodies can be selected for the enterprise cloud computing information service platform to form a comprehensive operation and view protection mechanism to enhance the security of the enterprise cloud computing application system. On the other hand, enterprises also need to enhance the encryption management of information and data. By optimizing the enterprise virtual machine software and enhancing the hardware system, the cloud computing and computer system can be promoted to Gree, thereby ensuring the security of corporate information and data and ensuring corporate information. The data transmission environment will not be damaged.

\subsection{Strengthen the Cybersecurity Awareness of Practitioners}

The development of accounting information is inseparable from the strong support of the network. As the basis of the development of accounting informationization, the network will directly affect the operating quality of the accounting information system. Therefore, enterprises should attach great importance to the security of accounting information networks. First, recruit and select professionals to engage in network security management. Dynamic monitoring of the network environment for the daily operation of the accounting information system can promptly deal with various attacks or security vulnerabilities faced by the network, and upgrade and maintain the network system according to the needs of the system operation, thereby comprehensively enhancing the network risk prevention capability; followed by the enterprise should Strengthen the promotion of network security, make all employees aware of the importance of accounting information network security for the development of enterprises, and establish and improve systems and measures related to corporate accounting information security, regularly carry out network suffocation-related training for employees, and use network security technology as The important content of the training, with a basic understanding of the current commonly used network security precautions and methods. At the same time, a dynamic midway network security prevention and control plan is required to provide the necessary guarantee for the safe and stable operation of the accounting system.

In the information age, companies' requirements for accounting personnel are not only limited to practitioners' professional ethics, basic accounting knowledge reserves, etc., but also require accounting personnel to have information technology literacy, be familiar with the accounting information business field, and master information retrieval Ability and strong sensitivity to accounting information.

\subsection{Improve the Prevention Level of Information Platform}

From a technical point of view, the following measures can be taken: First, strengthen the authentication and verification of platform users, and design differentiated login interfaces according to different user types. Not only must traditional login passwords be set, but also facial Recognition and other biological information recognition methods are used to enhance system login; the second is to strengthen the complexity of data keys to enhance data security, comprehensively considering the two levels of hardware and software, and gradually build a more secure data encryption system . In the application of virtual machine technology, necessary security prevention and control measures should be taken to reduce the possibility of attack during data operation; third, timely data backup should be done. The purpose of data backup is to reduce the loss caused by various factors such as data loss or damage. In the era of big data, data has become an important asset of enterprises. It is necessary to make physical backups of all kinds of data generated by enterprises in a timely manner, and to regularly maintain related storage devices to ensure data security.

\section{CONCLUSIONS}

This paper expounds the impact of the rapid development of the information age on accounting information, provides a more mature resource sharing platform for the development of accounting information, ensures that the cost of accounting information is effectively optimized, and improves the development trend of accounting information. The efficiency of accounting information also covers the problems existing in the security of accounting information, from improving the independence of the information platform. Strengthen the data security of the information platform, strengthen the security awareness of personnel communication, and improve the risk prevention level of information platform, put forward measures to solve the accounting information security issues in the era of big data to ensure the healthy and sustainable development of accounting information. Research on the impact of information technology on corporate accounting has greatly improved the professional level of accounting 
personnel and promoted the efficient and rapid development of enterprises. Whether in the information field or the financial field, it is of great significance.

\section{ACKNOWLEDGMENTS}

(1)Liming Vocational University on Approving the Establishment of School-level General Projects in 2020 (Li Da [2020] No. 43) "University Network Ideological Security Related Issues and countermeasures research" (LAS202028)

(2)The thirteenth Five-year Plan of Fujian provincial Ministry of Education, Project of 2020. "Reach on the cultivation of "Craftsman Spirit" in undergraduate specialty teaching in colleges and universities" (FJJKCG20- 6)

(3)The 2020 Lifelong Education Research Project in Fujian Province "Research on the Construction of the Intelligent Elderly Care Service System in Fujian Community Based on the Concept of Lifelong Education-Taking Xiamen as an Example" (ZS20236)

(4)The 2020 academic research fund project of Xiamen Institute of Technology Business School

\section{REFERENCES}

[1] McKinney, Earl, Yoos, Charles J, Snead, Ken. The need for 'skeptical' accountants in the era of Big Data [J]. Journal of Accounting Education, 2016, 38:63-80.

[2] Peng Chaoran. Risk factors and preventive measures of accounting informationization in the era of big data $[\mathrm{J}]$. Financial Research, 2014.9(4):73-76.

[3] Li Weixia. Research on Enterprise Accounting Informationization Risk and Control Based on Big Data [J]. Finance and Accounting Newsletter, 2018, 789(25): 105-108

[4] Qi Xuan. A review of the research on the relevance of accounting information in the era of big data [J]. Finance and Accounting Newsletter, 2015, 684(28): 62-65.

[5] Wu Ting, Qiao Yinhua. Discussion on professional ability construction of management accounting in the era of big data [J]. Friends of Accounting, 2017, 34(19): 38-42.

[6] Cheng Ping, Fan Ke. Research on the Information Ecosystem Based on Cloud Accounting in the Big Data Era [J]. Friends of Accounting 2015, 27(20): 131-134.
[7] Zhang Chao's domestic research review of management accounting informatization [J] Finance and Accounting Monthly, 2015(28): 101105.

[8] Jia Haibo. Analysis of corporate financial management in the era of big data $[\mathrm{J}]$. Finance and Accounting, 2014, 41(9): 36-36

[9] Lichen. cross-border acquisitions by Chinese enterprise: The benefits and disadvantages of political connections $[\mathrm{J}]$. Journal of CorporateFinance, 2019, 18(12):21-24. 